\title{
25. EARLY CRETACEOUS MAGNETOSTRATIGRAPHY AND PALEOLATITUDES FROM THE MID-PACIFIC MOUNTAINS: PRELIMINARY RESULTS BEARING ON GUYOT FORMATION AND PACIFIC PLATE TRANSLATION ${ }^{1}$
}

\author{
John A. Tarduno, ${ }^{2}$ William W. Sager, ${ }^{3}$ and Yoshifumi Nogi ${ }^{4}$
}

\begin{abstract}
Detailed thermal demagnetization experiments applied to some weakly magnetized shallow-water carbonates recovered at Site 866 (991-1622 mbsf) yield a characteristic remanent magnetization having maximum unblocking temperatures of $500^{\circ}$ to $580^{\circ} \mathrm{C}$, after the removal of one or more overprints. Alternating field (AF) demagnetization yields a similar characteristic component. This magnetization shows both polarities, which form 10 polarity zones that we correlate to the upper Mesozoic "M-sequence" of the marine magnetic anomaly record. Using tie points derived from paleontologic and isotopic studies, we tentatively assign the polarity zones to CM1 through CM7. Such an assignment requires that basement at Site 866 be of M7 age (or older), broadly consistent with radiometric age data that suggest an age of $128 \mathrm{Ma}$. Using this interpretation, at least one major hiatus and several substantial changes in sedimentation rate are required in the carbonate sequence.

Paleolatitude data from the Site 866 carbonates $\left(14.6^{\circ} \mathrm{S}\right)$ are within error of an early Aptian data set from nearby Site 463 $\left(13^{\circ} \mathrm{S}\right.$ ), suggesting little (or no) latitudinal transport during the later part of the Early Cretaceous. Comparisons with younger data sets also suggest that total latitudinal translation from the time of edifice formation to the mid-Cretaceous was minor $\left( \pm 5^{\circ}\right)$. These data do not support drift toward extreme southerly latitudes as a cause of platform drowning. This near-stationary behavior of the Pacific Plate over an area of vigorous mantle convection may account for some patterns of subsidence that are implied by the magnetostratigraphic data.
\end{abstract}

\section{INTRODUCTION}

Site 866 , drilled on Resolution Guyot $\left(21.3^{\circ} \mathrm{N}, 174.3^{\circ} \mathrm{E}\right)$ in the Mid-Pacific Mountains (Sager, Winterer, Firth, et al., 1993), provides one the opportunity to study the evolution of a large Early Cretaceous oceanic crustal swell. During Leg 143, approximately $1620 \mathrm{~m}$ of shallow-water limestone and $124 \mathrm{~m}$ of basalt were penetrated (see Sager, Winterer, Firth, et al., 1993, for a detailed lithologic description of the sequence). In this study, we attempt to use the paleomagnetic record to determine simultaneously two factors bearing on guyot formation and subsequent drowning: crustal subsidence and Pacific Plate translation. Because the carbonates recovered at Site 866 also were deposited in the photic zone, they record sea level; sedimentation rates derived from magnetostratigraphy can be used to constrain subsidence with the caveat that eustatic changes in sea level are relatively small. In addition, the inclination record of the carbonates, if not completely overprinted by diagenetic processes or affected by inclination shallowing, can yield information about the latitudinal history of the guyot, a key factor for choosing between various proposed causes of platform drowning.

\section{METHODS}

Stepwise demagnetizations were applied to all samples (i.e., no blanket demagnetizations were applied) in $25^{\circ} \mathrm{C}$ temperature increments. A limited number of AF demagnetizations (2.5-5 mT increments) also were attempted. Thermal demagnetization appeared to be the more successful approach. Part of this success may be related to the low natural remanent magnetization intensities of many samples

\footnotetext{
' Winterer, E.L., Sager, W.W., Firth, J.V., and Sinton, J.M. (Eds.), 1995, Proc. ODP, Sci. Results, 143: College Station (Ocean Drilling Program).

${ }^{2}$ Department of Earth and Environmental Sciences, University of Rochester, Rochester, NY 14627, U.S.A.

${ }^{3}$ Departments of Oceanography and Geophysics, Texas A\&M University, College Station, TX 77843, U.S.A.

${ }^{4}$ Geochemical Research Department, Meteorological Research Institute, 1-1 Nagamine, Tsukuba, Ibaraki, 305, Japan.
}

$\left(3 \times 10^{-8}\right.$ to $\left.1 \times 10^{-7} \mathrm{emu}\right)$. In these weakly magnetized samples, any spurious magnetization acquired during $\mathrm{AF}$ treatment can obscure a primary signal.

Demagnetization behavior varies throughout the sequence and is related to the variable presence of overprints. There appear to be three types of overprint. In most samples, these overprints are removed progressively with increasing temperature in the same order, aiding in their identification. The first component removed is one that plagues much deep-sea drilling data: a steeply inclined strong magnetization related to some not-as-yet completely understood processes of the drill string. The second overprint is that of the presentday field at the site. The third overprint, observed in only a few samples, appears to be a normal field overprint that was acquired while the site was still in the Southern Hemisphere. This last overprint also was observed in paleomagnetic data obtained from pelagic carbonates from nearby DSDP Site 463 (Sayre, 1981; Tarduno et al., 1989), drilled on the apron of Resolution Guyot.

In general, characteristic magnetizations had maximum unblocking temperatures of $500^{\circ}$ to $580^{\circ} \mathrm{C}$, which is consistent with a titanomagnetite carrier (Fig. 1). No coherent hematite directions were observed at higher temperatures. Of 93 samples measured, only 78 yielded characteristic magnetizations. Based-on these characteristic magnetizations, we recognized the following 10 polarity zones (Fig. 2): normal polarity Zone $\mathrm{H}+(991.0-1054.2 \mathrm{mbsf})$; reversed polarity Zone H- (1054.2-1218.7 mbsf); normal polarity Zone I+ (1218.7$1324.1 \mathrm{mbsf})$; reversed polarity Zone I-(1324.1-1357.8 mbsf); normal polarity Zone J+ (1357.8-1396.0 mbsf); reversed polarity Zone J-(1396.0-1441.4 mbsf); normal polarity Zone K+ (1441.4-1475.3 mbsf); reversed polarity Zone K- (1475.3-1532.6 mbsf); normal polarity Zone L+(1532.6-1594.5 mbsf); and reversed polarity Zone L- (>1594.5 mbsf).

\section{DISCUSSION}

Before any detailed shore-based measurements were made, two shipboard observations raised concerns about the fidelity of the magnetization carried by the shallow-water carbonates. First, pyrite was observed in several cores, indicating potential complications posed 


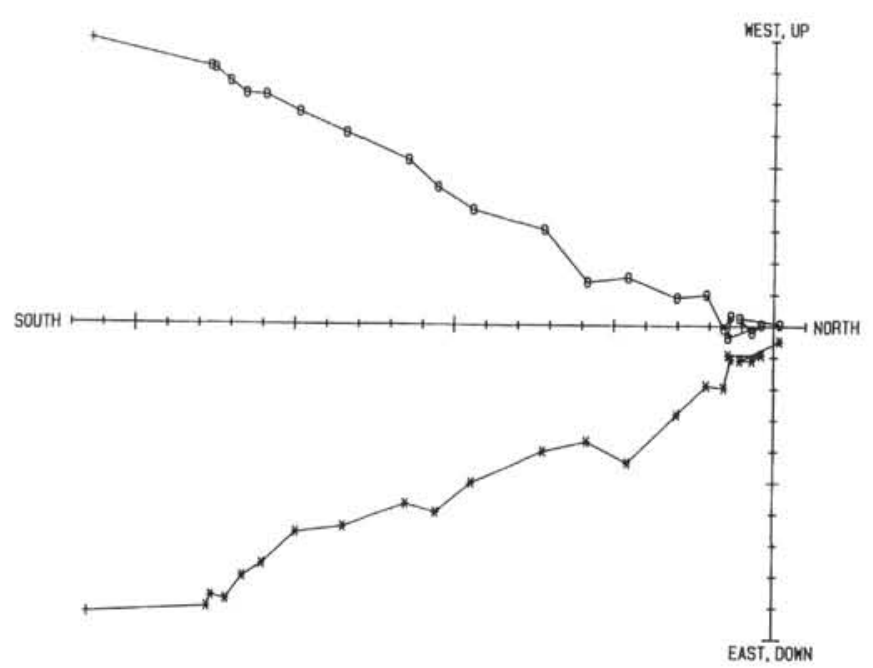

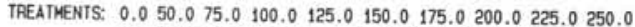
$275.0 \quad 300.0 \quad 325.0 \quad 350.0 \quad 375.0 \quad 400.0 \quad 425.0 \quad 450.0475 .0$ 500.0525 .0550 .0575 .0

Figure 1. Orthogonal vector plot of the progressive thermal demagnetization of a shallow-water carbonate sample from Site 866 (Sample 143-866A-133R-3, $27 \mathrm{~cm})$. Temperature increments $\left({ }^{\circ} \mathrm{C}\right)$ are shown. Axis ticks are $1.0 \times 10^{-7} \mathrm{emu}$.

by reduction diagenesis. The effect of reduction diagenesis on magnetization properties, first documented in hemipelagic regions (Karlin and Levi, 1983, 1985; Karlin, 1990; Leslie et al., 1990), has more recently been noted in pelagic sediments (Sager, 1988), including those having very high carbonate values (Musgrave et al., 1993) similar to those of Site 866 .

The presence of pyrite implicates sulfate reduction and the production of $\mathrm{H}_{2} \mathrm{~S}$, which combines with ferric iron in the magnetite lattice (Canfield and Berner, 1987). Pyrite alone, however, does not necessarily denote the large-scale destruction of a primary magnetic signal. In uplifted pelagic carbonates of the Apennines and Southern Alps (northern Italy), arguably the best sedimentary record of Mesozoic geomagnetic polarity (e.g., Lowrie et al., 1980), pyrite and reduction diagenesis are thought to be localized, tied to fluctuating organic carbon input (Tarduno, 1992).

Such a fluctuating organic carbon input probably plays a part in the weak magnetic intensities observed in the section and in samples that did not preserve a primary magnetization. However, reduction diagenesis apparently was not sufficiently severe to destroy completely a polarity record. The exact reasons for this survival are unclear, but they may be related to a high initial magnetic input related to the erosion of the volcanic edifice. Minor sulfides, other than pyrite, may also be present in some intervals, but they do not appear to have obscured the magnetic polarity pattern.

The second concern centers on the effect of dolomitization, which was observed in varying degrees in the lower portion of the carbonate sequence (Sager, Winterer, Firth, et al., 1993). Furthermore, shorebased $\mathrm{Sr}$ data have been interpreted as indicating a Tertiary age for the dolomite in certain intervals (Flood, this volume). Several observations, however, are inconsistent with dolomitization contributing a substantial secondary magnetization in the sequence. First, no correlation exists between the magnetic polarity intervals and the dolomite lithologic units. Second, there is no widespread occurrence of very shallow magnetizations, which would be consistent with a Tertiaryage magnetization acquired while the site was closer to the equator. The characteristic magnetizations form well-defined polarity zones, and transitional samples may also be present (Fig. 2). The average inclination is consistent with other Pacific Plate data, indicating a

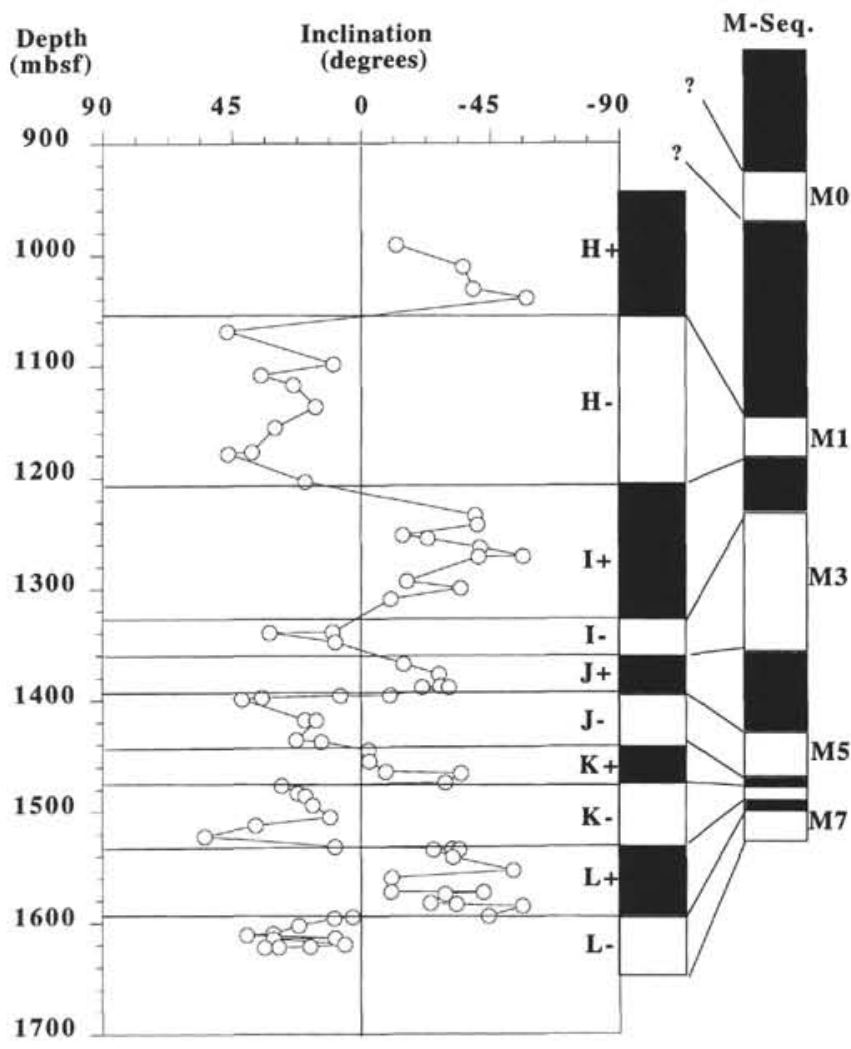

Figure 2. Preliminary magnetostratigraphy and correlations from characteristic remanent magnetizations derived from Site 866 . Ten polarity zones (labeled $\mathrm{H}+$ to $\mathrm{L}-$ ) are identified (the site was in the Southern Hemisphere during deposition). These polarity zones are tied to the marine magnetic anomaly sequence (M-seq. from Harland et al., 1990), based on biostratigraphic, isotopic, and radiometric tie points (see text).

Southern Hemisphere origin during Early Cretaceous time. Thus, we feel there is strong observational evidence that dolomitization has not seriously compromised the magnetic polarity signal. Instead, the data are in general agreement with recent studies that indicate that a primary magnetization can be preserved in dolomitized rocks (McNeill and Kirschvink, 1993).

\section{Tentative Polarity Interpretation}

Correlations of our polarity sequence to the geomagnetic time scale are hampered by the absence of a supportable assumption, such as constant sedimentation rates, that guides us in some pelagic environments. Therefore, we must rely even more heavily on tie points derived from other stratigraphic data. The $\mathrm{C}$-isotope data suggest an Aptian/Barremian boundary near $900 \mathrm{mbsf}$ and a Barremian/Hautervian boundary near 1425 to 1500 mbsf (Jenkyns, this volume). Benthic foraminifers are in general agreement with these isotopic data, suggesting placement of the Aptian/Barremian boundary between 800 and 1100 mbsf and an Hauterivian age at the base of the sediment sequence (Arnaud and Sliter, pers. comm., 1993). Radiometric data for basaltic basement suggest an age of $128 \mathrm{Ma}$ (Pringle and Duncan, this volume), which is broadly consistent with other radiometric data that suggest an Hautervian age at the base of Site 866 (Harland et al., 1990).

Reversed polarity Chron CM0 is thought to lie entirely within the early Aptian (Tarduno et al., 1989), not across the Aptian/Barremian boundary, as depicted in some time scales (Harland et al., 1990). The lower boundary of $\mathrm{CM} 0$, however, falls close to the Aptian/Barremian boundary. Therefore, the top of our magnetostratigraphic column probably represents the upper Barremian. We assigned the first re- 
versed polarity interval ( $\mathrm{H}-)$ to $\mathrm{CM} 1$; subsequent reversed polarity intervals were assigned to $\mathrm{CM} 3$ through $\mathrm{CM} 7$. Such a correlation assumes that all polarity chronozones are present; substantial gaps in the section would result in an underestimated age for the guyot basement. Older basement ages, however, would become difficult to reconcile with radiometric data for basaltic basement. The most surprising aspect of the polarity zone assignment, the correlation of the narrowest polarity zones (I-) with the longest polarity chronozones (CM3), indicates that at least one major break is present in the section (possibly within the coral peloidal grainstones of lithologic Subunit VIIC). After this apparent hiatus, sedimentation rates increase (M2-M1) relative to the lower sequence (M7-M4) by approximately a factor of 2 . This change in sedimentation is opposite that expected for the subsidence of a seamount emplaced on normal oceanic crust, implying a phase of anomalously slow subsidence early in the guyot's history.

We stress, however, that correlations to polarity chronozones in these types of sediments cannot rest on magnetics alone (i.e., spacing of polarity zones). The present interpretation is based on currently available paleontologic, isotopic, and radiometric tie points. Given revisions in (or the selective use of) these tie points, other interpretations (such as the obvious correlation of $\mathrm{H}$ - to $\mathrm{CM} 3$ ) could be made.

\section{Paleolatitude Data}

The characteristic magnetizations are approximately half normally magnetized and half reversely magnetized (Fig. 3). Accounting for biases in inclination averages using the method of McFadden and Reid (1982), the mean of the normal polarity data $\left(I_{n}=-29.9^{\circ}+7.0, n\right.$ $=40, k=14$ ) is slightly steeper than that of the reversed polarity data $\left(I_{r}=-24.9^{\circ}+4.3, n=38, k=20\right)$, but the difference is not significant at the $95 \%$ confidence level. The combined data set $\left(I_{c}=-27.5^{\circ}{ }_{-4.8}\right.$, $n=78, k=16$ ) yields a mean paleolatitude of $14.6^{\circ} \mathrm{S}$.

Any paleolatitude derived from deep-sea sediments must be viewed in light of the possibility of inclination error (King, 1955, Blow and Hamilton, 1978) or compaction-induced inclination flattening (e.g., Anson and Kodama, 1987). Pacific deep-sea sediments of Cretaceous age are anomalously shallow, compared to nonsediment data sets (Gordon, 1990); the distribution of shallowing appears to be consistent with a compaction-induced effect (Tarduno, 1990). The paleolatitude derived from Site 866 , however, is indistinguishable from that obtained from nearby DSDP Site 463, the only site from the Pacific Ocean that does not yield anomalously shallow inclination values (Tarduno, 1990). The reason Site 463 was thought to have escaped the effect of compaction was because of early silification. Sediments from Site 866 may have escaped for another reason: sedimentologic studies (Sager, Winterer, Firth, et al., 1993) indicate that compaction of these shallow-water carbonates has been extremely minor.

The Aptian age paleolatitude value derived from DSDP Site 463 $\left(13^{\circ} \mathrm{S}\right)$, when compared to the Site 866 mean paleolatitude, implies little (or no) latitudinal motion of the site from Hauterivian to Aptian time. Furthermore, these data can be compared to an upper Albian data set available from Site $865\left(18.4^{\circ} \mathrm{N}, 180.4^{\circ} \mathrm{E}\right)$ (Sager and Tarduno, this volume) that yields a paleolatitude of $14.3^{\circ} \mathrm{S}$, suggesting that total latitudinal transport between this time interval ( $\sim 30 \mathrm{~m} . \mathrm{y}$.) cannot exceed that suggested by the present-day latitudinal separation of the two sites $(322.5 \mathrm{~km} \mathrm{~N})$.

We draw two general conclusions from these comparisons. First, models that suggest that platform drowning in the Mid-Pacific Mountains is related to southward drift (Winterer and Metzler, 1984) cannot be supported; other causes must be sought to account for platform drowning. Second, this slow latitudinal motion may hold clues about the subsidence history of the guyot. Although the Early Cretaceous Pacific Plate may have had a minor longitudinal component of motion, possibly accounting for some of the geomorphic trends of the Mid-Pacific Mountains, overall absolute motions were small. Subsidence may have been anomalously slow early in the history of Reso-

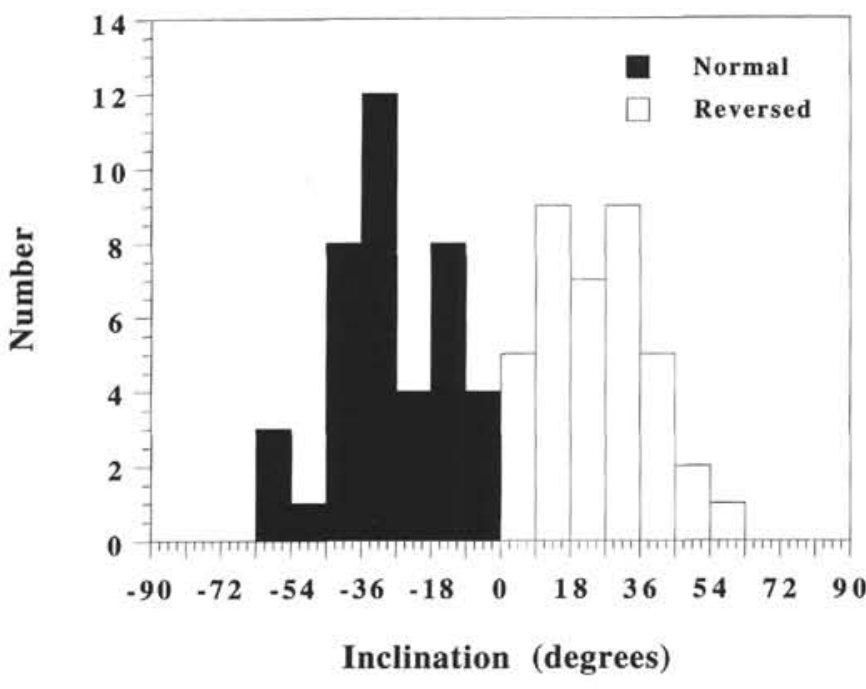

Figure 3. Histogram of inclination values derived from characteristic remanent magnetizations of Site 866 .

lution Guyot, because the site remained over an area of high convective mantle flow for about 30 m.y. A more quantitative evaluation of this suggestion, however, must await a more general reconsideration of Early Cretaceous time scales.

\section{ACKNOWLEDGMENTS}

J.T and W.S. were partially supported by USSSP grants. J.T also gratefully acknowledges the Keck Foundation for support to L. Tauxe for the Scripps Paleomagnetic Facility. We also thank Sheri Wu and Chris White for sample measurements and J. Ogg and an anonymous reviewer for review of the manuscript.

\section{REFERENCES}

Anson, G.L., and Kodama, K.P., 1987. The effects of compaction on a synthetic PDRM. Geophys. J.R. Astron. Soc., 88:673-692.

Blow, R.A., and Hamilton, N., 1978. Effect of compaction on the acquisition of a detrital remanent magnetisation in fine-grained sediments. Geophys. J. R. Astron. Soc., 52:13-23.

Canfield, D.E., and Berner, R.A., 1987. Dissolution and pyritization of magnetite in anoxic marine sediments. Geochim. Cosmochim. Acta, 51:645659.

Gordon, R., 1990. Test for bias in paleomagnetically determined paleolatitudes from Pacific Plate Deep Sea Drilling Project sediments. J. Geophys. Res., 95:8397-8404.

Harland, W.B., Armstrong, R.L., Cox, A.V., Craig, L.E., Smith, A.G., and Smith, D.G., 1990. A Geologic Time Scale 1989: Cambridge (Cambridge Univ. Press).

Karlin, R., 1990. Magnetite mineral diagenesis in suboxic sediments at Bettis Site W-N, NE Pacific Ocean. J. Geophys. Res., 95:4421-4436.

Karlin, R., and Levi, S., 1983. Diagenesis of magnetic minerals in recent hemipelagic sediments. Nature, 303:327-330.

-, 1985. Geochemical and sedimentological control of the magnetic properties of hemipelagic sediments. J. Geophys. Res., 90:10373-10392.

King, R.F., 1955. The remanent magnetism of artificially deposited sediments. Mon. Not. R. Astron. Soc., Geophys. Suppl., 7:115-134.

Leslie, B.W., Lund S., and Hammond, D.E., 1990. Rock magnetic evidence for the dissolution and authigenic growth of magnetic minerals within anoxic marine sediments of the California Continental Borderland. $J$. Geophys. Res., 95:4437-4452.

\footnotetext{
"Abbreviations for names of organizations and publication titles in ODP reference lists follow the style given in Chemical Abstracts Service Source Index (published by American Chemical Society).
} 
Lowrie, W., Alvarez, W., Premoli Silva, I., and Monechi, S., 1980. Lower Cretaceous magnetic stratigraphy in Umbrian pelagic carbonate rocks. Geophys. J.R. Astron. Soc., 60:263-281.

McFadden, P.L., and Reid, A.B., 1982. Analysis of paleomagnetic inclination data. Geophys. J. R. Astron. Soc., 69:307-319.

McNeill, D.F., and Kirschvink, J.L., 1993. Early dolomitization of platform carbonates and the preservation of magnetic polarity. J. Geophys. Res., 98:7977-7986.

Musgrave, R.J., Delaney, M.L., Stax, R., and Tarduno, J.A., 1993. Magnetic diagenesis, organic input, interstitial water chemistry, and paleomagnetic record of the carbonate sequence on the Ontong Java Plateau. In Berger, W.H., Kroenke, L.W., Mayer, L.A., et al., Proc. ODP, Sci. Results, 130: College Station, TX (Ocean Drilling Program), 527-546.

Sager, W.W., 1988. Paleomagnetism of Ocean Drilling Program Leg 101 sediments: magnetostratigraphy, magnetic diagenesis, and paleolatitudes. In Austin, J.A., Jr., Schlager, W., et al., Proc. ODP, Sci. Results, 101: College Station, TX (Ocean Drilling Program), 327-360.

Sager, W.W., Winterer, E.L., Firth, J.V., et al., 1993. Proc. ODP, Init. Repts., 143: College Station, TX (Ocean Drilling Program).

Sayre, W.O., 1981. Preliminary report on the paleomagnetism of Aptian and Albian limestones and trachytes from the Mid-Pacific Mountains and Hess
Rise, Deep Sea Drilling Project Leg 62. In Thiede, J., Vallier, T.L., et al., Init. Repts. DSDP, 62: Washington (U.S. Govt. Printing Office), 983-994.

Tarduno, J.A., 1990. Absolute inclination values from deep sea sediments: a reexamination of the Cretaceous Pacific record. Geophys. Res. Lett., 17:101-104.

-1992 . Magnetic susceptibility cyclicity and magnetic dissolution in Cretaceous limestones of the Southern Alps (Italy). Geophys. Res. Lett., 19:1515-1518.

Tarduno, J.A., Sliter, W.V., Bralower, T.J., McWilliams, M., Premoli Silva, I., and Ogg, J.G., 1989. M-sequence reversals recorded in DSDP sediment cores from the western Mid-Pacific Mountains and Magellan Rise. Geol. Soc. Am. Bull., 101:1306-1316.

Winterer, E.L., and Metzler, C.V., 1984. Origin and subsidence of guyots in Mid-Pacific Mountains. J. Geophys. Res., 89:9969-9979.

Date of initial receipt: 1 December 1993

Date of acceptance: 26 May 1994

Ms 143SR-241 